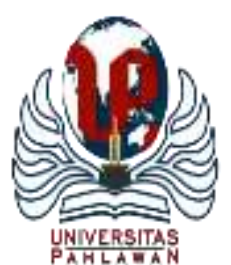

Edukatif : Jurnal Ilmu Pendidikan Volume 3 Nomor 6 Tahun 2021 Halm 4786 - 4793

EDUKATIF: JURNAL ILMU PENDIDIKAN

Research \& Learning in Education

https://edukatif.org/index.php/edukatif/index

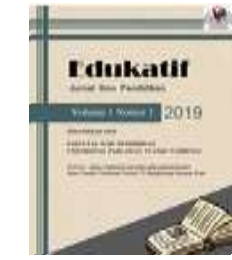

\title{
Perbedaan Hasil Belajar ditinjau dari Pemahaman Konsep dan Perhitungan Matematis pada Pembelajaran Fisika Terapan
}

\author{
Lusiani $^{凶}$ \\ Akademi Maritim Nusantara, Indonesia \\ E-mail : anilusi0287@gmail.com
}

\begin{abstract}
Abstrak
Tujuan yang akan dicapai yakni menganalisis perbedaan hasil belajar ditinjau dari Pemahaman Konsep dan Perhitungan Matematis pada Pembelajaran Fisika Terapan. Kajian ini menggunakan metode penelitian kuantitatif. Penelitian dilakukan bulan September 2020 dengan subjek kajian taruna Teknika dan Nautika yang mengikuti pembelajaran fisika terapan dengan sampel sejumlah 30 responden. Simpulan pada kajian ini yakni terdapat perbedaan signifikan hasil belajar fisika terapan terkait pemahaman konsep dan perhitungan matematis pada taruna teknika nautika. Pada penyelesaian soal pemahaman konsep mendapat nilai tertinggi yakni 86, sedangkan pada penyelesaian soal perhitungan matematis mendapat nilai tertinggi yakni 61. Saat penyelesaian soal perhitungan matematis taruna memiliki kesulitan tersendiri lebih dari kesulitan pemahaman konsep yakni saat menghitung menggunakan prinsip matematika dasar, masih belum tepat saat melakukan perhitungan, selain itu taruna menggunakan rumus yang kurang tepat hingga jawaban akhir yang dihasilkan tidak sesuai. Sehingga analisis perbedaan hasil belajar baik secara kuantitatif maupun kualitatif menunjukkan adanya perbedaan yang signifikan.
\end{abstract}

Kata Kunci: Hasil Belajar, Pemahaman Konsep, Perhitungan Matematis.

\section{Abstract}

The goal to be achieved is to analyze differences in learning outcomes in terms of Concept Understanding and Mathematical Calculations in Applied Physics Learning. This study uses quantitative research methods. The research was conducted in September 2020 with the subject of the study of Technical and Nautical cadets who took part in applied physics learning with a sample of 30 respondents. The conclusion in this study is that there are significant differences in the learning outcomes of applied physics related to understanding concepts and mathematical calculations in nautical engineering cadets. In solving the problem of understanding the concept, the highest score is 86 , while in solving the problem of mathematical calculation the highest score is 61. When solving the problem of mathematical calculation, cadets have their own difficulties more than the difficulty of understanding the concept, namely when calculating using basic mathematical principles, it is still not right when doing In addition, the cadets use an inaccurate formula so that the final answer is not appropriate. So, the analysis of differences in learning outcomes both quantitatively and qualitatively shows a significant difference.

Keywords: Learning Outcomes, Concept Understanding, Mathematical Calculations

Copyright (c) 2021 Lusiani

$\triangle$ Corresponding author:

Email : anilusi0287@gmail.com

DOI : https://doi.org/10.31004/edukatif.v3i6.1493

ISSN 2656-8063 (Media Cetak)

ISSN 2656-8071 (Media Online)

Edukatif : Jurnal Ilmu Pendidikan Vol 3 No 6 Tahun 2021 p-ISSN 2656-8063 e-ISSN 2656-8071 
4787 Perbedaan Hasil Belajar ditinjau dari Pemahaman Konsep dan Perhitungan Matematis pada Pembelajaran Fisika Terapan - Lusiani

DOI: https://doi.org/10.31004/edukatif.v3i6.1493

\section{PENDAHULUAN}

Belajar yakni aktivitas yang dinilai penting, selain itu belajar merupakan salah satu penentu baik maupun tidaknya mutu pendidikan. (Amaliyah et al., 2021). Pembelajaran merupakan aktivitas yang direncanakan murid melalui arahan, bimbingan maupun bantuan dari Guru dalam mendapatkan adanya perubahan. (Betwan, 2019). Belajar dapat membuka jendela pemahaman individu terkait makna beragam hal. Melalui belajar, individu bisa mengerti makna diri, lingkungan, serta hakikat pencipta diri beserta lingkungannya.(Rahmawati \& Ali, n.d.) Proses belajar-mengajar yakni sebuah proses yang memiliki serangkaian aktivitas pendidik serta peserta didik berdasar dasar relevansi timbal balik.(Hakim \& Rambe, 2012)

Setelah KBM diperlukan untuk mengadakan penilaian yang bertujuan bahwa pendidik bisa mendapatkan data perkembangan kemampuan yang ada pada diri masing-masing peserta didik secara utuh, Penilaian akan lebih berarti jika pendidik melakukan penilaian lebih dari 1 kali, bahkan seringkali supaya bia memonitor perkembangan kemampuan peserta didik secara berkelanjutan selain itu dapat menjadi tolak ukur ketercapaian tujuan pembelajaran. (Nurbudiyani, 2013)

Hasil belajar merupakan suatu penilaian akhir dimulai proses serta pengenalan yang sudah dilaksanakan berulang kali. Selain itu dapat terekam pada janka panjang, bisa juga tidak hilang sampai batas waktu lama sebab hasil belajar ikut andil saat pembentukan pribadi seseorang yang selalu ingin mencapai hasil maksimal hingga dapat merubah pola pikir dan menciptakan kinerja yang meningkat.(Sulastri et al., 2015). Prestasi belajar yakni hasil yang diperoleh peserta didik saat KBM. Prestasi belajar tersebut dilihat dari segi kognitif, afektif, psikomotorik.(Djazari \& Sagoro, 2011).

Penguasaan materi pelajaran serta penggunaan pengetahuan yakni menambahnya ilmu pengetahuan individu yang merupkan hasil tahap belajar bukan dikarenakan penyebab lainnya, dinamakan aspek kognitif. Hasil tahap belajar keterampilan yakni terampil melaksanakan beragam aktivitas dinamakan psikomotorik serta hasil tahap belajar kemampuan menilai sikap serta perilaku pada beragam segi kehidupan dinamakan aspek afektif. Murid disebut telah berhasil dalam belajar apabila sudah tercapai ketiga aspek tersebut.(Azmi et al., 2017)

Hasil belajar merupakan perubahan keterampilan serta kecakapan, kebiasaan sikap, pengertian, pengetahuan, serta apresiasi, disebut kognitif (pemahaman konsep), afektif, serta psikomotor (pemahaman proses) melalui perbuatan belajar. Pemahaman Konsep, didefinisikan kemampuan menerima makna suatu materi yang dipelajari. Hasil belajar yakni perubahan tingkah laku yang didapat peserta didik setelah memperoleh KBM. Segi yang diperoleh berupa perubahan tingkah laku yang tergantung dari hal yang dipelajari oleh murid. Apabila murid mempelajari pengetahuan terkait konsep, maka perubahan tingkah laku yang didapat yakni berupa penguasaan konsep. (Mahananingtyas, 2017). Hasil belajar ditandai adanya perubahan perilaku menyeluruh dalam cakupan ranah kognitif, psikomotor, afektif. Tahap perubahan dimulai dari yang paling sederhana hingga yang paling kompleks.(Nurtanto \& Sofyan, 2015)

Nilai hasil belajar merupakan salah satu indikator yang dapat dimanfaatkan dalam pengukuran keberhasilan individu dalam belajar. Nilai tersebut mendeskripsikan hasil yang diperoleh individu dari aspek kognitif, afektif, psikomotorik.(Maisaroh \& Rostrieningsih, 2010)

Mata pelajaran/perkuliahan fisika yakni salah satu mapel/makul IPA yang di dalam KBMnya peserta didik diharapkan bisa berfikir menyeluruh, objektif, kreatif, logis untuk mengenal perubahan serta fenomena yang ada dialam semesta dalam keseharian. (Hanifah, 2016)

Fisika menjadi salah satu bagian ilmu sains yang menuntut peserta didik berfikir kreatif serta terampil sebab materi dalam fisika membutuhkan pemahaman dibandingkan pengahafalan. Pada materi fisika peserta didik diharuskan dapat mengerti kaitan antara konsep fisis dengan konsep matematis, sebab 2 konsep tersebut merupakan satu kesatuan pada ilmu fisika. (Hidayatulloh, 2020) 
4788 Perbedaan Hasil Belajar ditinjau dari Pemahaman Konsep dan Perhitungan Matematis pada Pembelajaran Fisika Terapan - Lusiani

DOI: https://doi.org/10.31004/edukatif.v3i6.1493

Salah satu tujuan pembelajaran sains khususnya fisika yakni memberi pemahaman. Dengan maksud bahwa belajar murid diharuskan bisa mengerti materi yang diberikan. (Kallesta et al., 2018)

Keterampilan berpikir sangat dibutuhkan saat belajar fisika, selain keterampilan berhitung, memanipulasi, observasi, dan keterampilan merespon sebuah problem secara kritis (Mundilarto,2002: 3-5). Sifat mata pelajaran fisika salah satunya yakni memiliki syarat, maksudnya tiap konsep baru terkadang ada tuntutan prasyarat pemahaman dari konsep sebelumnya. (Kallesta et al., 2018)

Sudjana dalam (Wulansari \& Hakim, 2015), menyampaikan terkait pemahaman dengan definisi kemampuan yang ada untuk memperoleh makna maupun menjelaskan suatu konsep, adanya kaitan antara suatu konsep terhadap makna didalamnya. Pemahaman yang ada pada individu adalah hasil belajar dari sebuah kondisi, situasi, orang lain serta objek lainnya yang bisa diterapkan lebih dari sebuah pemahaman. (Nurfajri \& Rochmawati, 2021)

Siswa merasa sulit mempelajari bunyi sebab sulit menghafalkan rumus. Erfan \& Ratu (2018) menyampaikan bahwa salah satu kesulitan murid saat belajar fisika yakni adanya kesulitan terletak pada matematikanya.(Kallesta et al., 2018)

Kajian Yadaeni (2016) menyampaikan terkait murid mendapat kesulitan untuk memahami prinsip hukum Pascal. Hasil wawancara guru diperoleh sebagian besar murid kesulitan mengerti rumus, menentukan satuan serta lemahnya pemahaman dasar-dasar matematika. Kajian Dewi dan Yusro (2016) menyampaikan kesulitan dalam pembelajaran IPA terletak pada fisika yakni rumus serta perhitungan. Sebagian besar murid memiliki alasan yakni fisika memiliki banyak rumus serta sulit dimengerti, hal lain yakni lemahnya kemampuan matematis murid. Putri et. al., (2018) menyampaikan murid mempunyai kendala yakni kurangnya kemampuan pada dasar matematika hingga murid kesulitan menggunakan operasi perhitungan saat penyelesaian soal materi tekanan.(Amaliyah et al., 2021)

Pada salah satu kategori sekolah yang digunakan sebagai subjek kajian, terdapat kesulitan berhitung dengan nilai 41,97\%, penguasaan konsep dengan nilai 41,46\%, serta kesulitan mendefinisikan lambang serta melakukan konversi satuan dengan nilai 40,92\%. (Haqiqi \& Sa'adah, 2018).

Kemampuan pemahaman matematis berhubungan terhadap kemampuan murid saat memahami sebuah konsep. Murid mampu mencapai tujuan pembelajaran jika mampu memahami konsep secara baik.(Putra et al., 2018)

Kesulitan menggunakan konsep yang diperoleh murid saat penyelesaian soal usaha serta energi yakni dengan nilai 20,61 \%, kesulitan menggunakan prinsip dengan nilai 30,30\%, kesulitan mengungkapkan informasi dengan nilai 20,00\%, kesulitan berhitung dengan nilai 29,09\%. Hal ini dikarenakan murid telah mengetahui teknik berhitung dengan tepat namun jarang latihan menghitung. (Nurjanah \& Sunarto, 2018).

Kesulitan yang diperoleh murid disebabkan beberapa hal yakni (1) tidak memahami soal hingga penerapan didalam rumus pun tidak tepat, (2) kesulitan saat penggunaan rumus yang tepat dengan permintaan soal, (3) kesulitan memahami hal yang diketahui serta yang ditanya dalam soal berbentuk cerita, (4) bisa mengetahui rumus yang digunakan namun tidak mampu saat penerapan matematisnya khususnya dalam perkalian silang serta akar.(Hidayatulloh, 2020)

Kesulitan belajar peserta didik di MTs Sunan Ampel dalam pembelajaran IPA yakni terletak pada lemahnya kemampuan matematis, kurangnya kemampuan saat pengembangan rumus saat dihadapkan pada persoalan, peserta didik kebingungan menggunakan rumus yang mana selain itu bingung saat mengkaitkan rumus satu dengan rumus lainnya, kelemahan dalam hal perhitungan merupakan permasalahan lainnya yang dialami peserta didik.(Dewi \& Yusro, 2016)

Yusuf dalam (Alfasina et al., 2019), kecerdasan logis matematis yakni kecakapan seseorang saat berpikir dengan logis, berfikir baik induktif maupun deduktif, kemampuan matematis saat mengolah beragam angka, kemampuan penyelesaian soal matematika dengan menjadikan polaserta mengkaitkannya secara logis. Sehingga saat belajar fisika dibutuhkan kemampuan numerik. (Nurfajri \& Rochmawati, 2021) 
4789 Perbedaan Hasil Belajar ditinjau dari Pemahaman Konsep dan Perhitungan Matematis pada Pembelajaran Fisika Terapan - Lusiani

DOI: https://doi.org/10.31004/edukatif.v3i6.1493

Hodiyanto (2017: 227) menyampaikan kemampuan komunikasi matematis murid yang diajarkan menggunakan model pembelajaran problem solving lebih baik dibandingkan kemampuan komunikasi matematis murid yang diberikan materi menggunakan model pembelajaran langsung. (Suardin \& Andriani, 2021)

Berdasarkan beberapa penjelasan tersebut, penulis tertarik untuk menganalisis perbedaan hasil belajar ditinjau dari Pemahaman Konsep dan Perhitungan Matematis pada Pembelajaran Fisika Terapan.

\section{METODE PENELITIAN}

Kajian ini menggunakan metode penelitian kuantitatif dan deskriptif kualitatif. Tujuan kajian yakni menganalisis perbedaan hasil belajar ditinjau dari pemahaman konsep dan perhitungan matematis pada pembelajaran fisika terapan serta mendeskripsikannya berbentuk kalimat naratif. Penelitian dilakukan pada bulan September 2020 dengan subjek kajian taruna teknika dan nautika yang mengikuti pembelajaran fisika terapan dengan sampel sejumlah 30 responden. Observasi dilakukan melalui pengamatan terhadap kegiatan belajar fisika terapan serta wawancara yang dilakukan terhadap peserta perkuliahan. Hasil belajar pada ranah kognitif diperoleh dengan menggunakan instrumen tes hasil belajar (google form) dengan 2 bentuk soal pemahaman konsep dan bentuk perhitungan matematis. Analisis kuantitatif menggunakan uji normalitas dan uji paired sample t-test dengan sampel yang sama namun 2 variabel yang dianalisis.

\section{HASIL DAN PEMBAHASAN PENELITIAN}

Hasil belajar pada ranah kognitif diperoleh dengan menggunakan instrumen tes hasil belajar (google form) dengan 2 bentuk soal pemahaman konsep dan bentuk perhitungan matematis. Data pre-test dan post-test pemahaman konsep fisika terapan dilakukan uji normalitas data terlebih dahulu menggunakan uji kolmogorovsmirnov. Hasil penelitian yang diperoleh pada kajian ini dapat dideskripsikan sebagai berikut:

1. Data hasil uji normalitas, dari data pre-test dan post-test soal fisika terapan

\section{NPar Tests}

Tabel 1

Hasil Uji Normalitas Data

\begin{tabular}{llr}
\hline \multicolumn{3}{c}{ One-Sample Kolmogorov-Smirnov Test } \\
\hline $\mathrm{N}$ & \multicolumn{1}{c}{$\begin{array}{c}\text { Unstandardize } \\
\text { d Residual }\end{array}$} \\
\hline Normal Parameters $^{\mathrm{a}}$ & Mean & 30 \\
\cline { 2 - 3 } & Std. Deviation & .0000000 \\
\hline Most Extreme & Absolute & .080 \\
\cline { 2 - 3 } Differences & Positive & .080 \\
\cline { 2 - 3 } & Negative & -.070 \\
\hline Kolmogorov-Smirnov Z & & .436 \\
\hline Asymp. Sig. (2-tailed) & & .991 \\
\hline
\end{tabular}

a. Test distribution is Normal.

Berdasarkan hasil uji normalitas, diperoleh nilai signifikansi 0,991 >0,05, maka dapat disimpulkan bahwa nilai residual berdistribusi normal.

2. Data hasil uji paired sample t-test, dari data pre-test dan post test pemahaman konsep dan perhitungan matematis fisika terapan

T-Test 
4790 Perbedaan Hasil Belajar ditinjau dari Pemahaman Konsep dan Perhitungan Matematis pada Pembelajaran Fisika Terapan - Lusiani

DOI: https://doi.org/10.31004/edukatif.v3i6.1493

Tabel 2

Tampilan Uji Statistik

Paired Samples Statistics

\begin{tabular}{lllrrr}
\hline & & Mean & N & Std. Deviation & \multicolumn{2}{c}{ Std. Error } \\
\hline \multirow{2}{*}{ Pair 1 } & Pemahaman konsep & 48.8667 & 30 & 20.18318 & 3.68493 \\
\cline { 2 - 6 } & Perhitungan matematis & 34.5667 & 30 & 16.46037 & 3.00524 \\
\hline
\end{tabular}

Tabel 3

Tampilan Uji Korelasi

Paired Samples Correlations

\begin{tabular}{lllll}
\hline & & $\mathrm{N}$ & Correlation & Sig. \\
\hline Pair 1 & $\begin{array}{l}\text { Pemahaman konsep \& } \\
\text { perhitungan matematis }\end{array}$ & 30 & .770 & .000 \\
\hline
\end{tabular}

Tabel 4

Tampilan Uji Beda

Paired Samples Test

Paired Differences

\begin{tabular}{|c|c|c|c|c|c|c|c|c|c|}
\hline & \multirow[b]{2}{*}{ Mean } & \multirow{2}{*}{$\begin{array}{c}\text { Std. } \\
\text { Deviation }\end{array}$} & \multirow[b]{2}{*}{ Std. Error Mean } & \multicolumn{2}{|c|}{$\begin{array}{l}\text { 95\% Confidence Interval } \\
\text { of the Difference }\end{array}$} & \multirow[b]{2}{*}{$\mathrm{t}$} & \multirow[b]{2}{*}{$\mathrm{df}$} & \multirow{2}{*}{$\begin{array}{l}\text { Sig. } \\
(2- \\
\text { tailed })\end{array}$} \\
\hline & & & & & Lower & Upper & & & \\
\hline $\begin{array}{l}\text { Pair } \\
1\end{array}$ & $\begin{array}{l}\text { Pemahaman konsep } \\
\text { - perhitungan } \\
\text { matematis }\end{array}$ & $1.43000 \mathrm{E} 1$ & 12.91925 & 2.35872 & 9.47587 & 19.12413 & $\begin{array}{r}6.06 \\
3\end{array}$ & 29 & .000 \\
\hline
\end{tabular}

Dasar pengambilan keputusan,

1) Jika nilai Sig. (2-tailed) <0,05, maka terdapat perbedaan yang signifikan antara hasil belajar pada data pemahaman konsep dan perhitungan matematis

2) Jika nilai Sig. (2-tailed) $>0,05$, maka tidak terdapat perbedaan yang signifikan antara hasil belajar pada data pemahaman konsep dan perhitungan matematis

Diketahui bahwa nilai Sig. (2-tailed) sebesar 0,000 <0,05, maka dapat disimpulkan bahwa terdapat perbedaan yang nyata antara hasil belajar pemahaman konsep dan perhitungan matematis.

Berdasarkan tampilan-tampilan tabel tersebut, dapat dideskripsikan beberapa hal antara lain: terdapat perbedaan yang nyata (signifikan) antara hasil belajar pemahaman konsep dan perhitungan matematis, dengan nilai nilai Sig. (2-tailed) sebesar 0,000 <0,05. Analisis dekriptif kualitatif dilakukan dengan mendeskripsikan tingkat kesulitan menyelesaikan soal fisika terapan dengan pengelompokan soal pemahaman konsep dan perhitungan matematis. Pada penyelesaian soal pemahaman konsep taruna mendapat nilai tertinggi yakni 86 , sedangkan pada penyelesaian soal perhitungan matematis mendapat nilai tertinggi yakni 61. Berdasarkan hasil wawancara terhadap taruna, saat penyelesaian soal perhitungan matematis taruna memiliki kesulitan tersendiri lebih dari kesulitan pemahaman konsep yakni saat menghitung menggunakan prinsip matematika dasar, masih belum tepat saat melakukan perhitungan, selain itu taruna menggunakan rumus yang kurang tepat hingga jawaban akhir yang dihasilkan tidak sesuai. Sehingga analisis perbedaan hasil belajar baik secara kuantitatif maupun kualitatif menunjukkan adanya perbedaan yang signifikan.

Sesuai yang disampaikan peneliti lain Erfan \& Ratu (2018) menyampaikan salah satu kesulitan murid saat belajar fisika yakni adanya kesulitan terletak pada matematikanya.(Kallesta et al., 2018). Kajian Yadaeni (2016) Hasil wawancara guru diperoleh sebagian besar murid kesulitan mengerti rumus, menentukan satuan 
4791 Perbedaan Hasil Belajar ditinjau dari Pemahaman Konsep dan Perhitungan Matematis pada Pembelajaran Fisika Terapan - Lusiani

DOI: https://doi.org/10.31004/edukatif.v3i6.1493

serta lemahnya pemahaman dasar-dasar matematika. Kajian Dewi dan Yusro (2016) menyampaikan kesulitan dalam pembelajaran IPA terletak pada fisika yakni rumus serta perhitungan. Sebagian besar murid memiliki alasan yakni fisika memiliki banyak rumus serta sulit dimengerti, hal lain yakni lemahnya kemampuan matematis murid. Putri et. al., (2018) menyampaikan murid mempunyai kendala yakni kurangnya kemampuan pada dasar matematika hingga murid kesulitan menggunakan operasi perhitungan saat penyelesaian soal materi tekanan.(Amaliyah et al., 2021). Pada salah satu kategori sekolah yang digunakan sebagai subjek kajian, terdapat kesulitan berhitung dengan nilai $41,97 \%$ yang merupakan prosentas tertinggi dibandingkan dengan aspek lainnya. (Haqiqi \& Sa'adah, 2018).Kemampuan pemahaman matematis berhubungan terhadap kemampuan murid saat memahami sebuah konsep. Murid mampu mencapai tujuan pembelajaran jika mampu memahami konsep secara baik.(Putra et al., 2018). Murid telah mengetahui teknik berhitung dengan tepat namun jarang latihan menghitung. (Nurjanah \& Sunarto, 2018). Kesulitan yang diperoleh murid salah satunya yakni bisa mengetahui rumus yang digunakan namun tidak mampu saat penerapan matematisnya khususnya dalam perkalian silang serta akar.(Hidayatulloh, 2020). Kesulitan belajar peserta didik di MTs Sunan Ampel dalam pembelajaran IPA yakni terletak pada lemahnya kemampuan matematis, kurangnya kemampuan saat pengembangan rumus saat dihadapkan pada persoalan, peserta didik kebingungan menggunakan rumus yang mana selain itu bingung saat mengkaitkan rumus satu dengan rumus lainnya, kelemahan dalam hal perhitungan merupakan permasalahan lainnya yang dialami peserta didik.(Dewi \& Yusro, 2016). Yusuf dalam (Alfasina et al., 2019), saat belajar fisika dibutuhkan kemampuan numerik. (Nurfajri \& Rochmawati, 2021).

Evaluasi dalam penelitian ini dengan adanya perbedaan hasil belajar ditinjau dari pemahaman konsep dan perhitungan matematis bahwa perlu ditindaklanjuti dengan menerapkan variasi metode pembelajaran yang digunakan. Salah satu metode pembelajaran yang direkomendasikan dalam hal ini yakni metode problem solving. Hal ini dikarenakan dengan menggunakan metode tersebut, terdapat beberapa langkah yang dapat digunakan untuk mengatasi permasalahan dasar matematis atau perhitungan matematis yang dapat terlihat dalam tahap-tahap problem solving.

Sejalan dengan yang disampaikan oleh Hodiyanto (2017: 227) menyampaikan kemampuan komunikasi matematis murid yang diajarkan menggunakan model pembelajaran problem solving lebih baik dibandingkan kemampuan komunikasi matematis murid yang diberikan materi menggunakan model pembelajaran langsung. (Suardin \& Andriani, 2021)

\section{KESIMPULAN}

Simpulan pada kajian ini yakni terdapat perbedaan signifikan hasil belajar fisika terapan terkait pemahaman konsep dan perhitungan matematis pada taruna teknika nautika. Pada penyelesaian soal pemahaman konsep mendapat nilai tertinggi yakni 86, sedangkan pada penyelesaian soal perhitungan matematis mendapat nilai tertinggi yakni 61. Saat penyelesaian soal perhitungan matematis taruna memiliki kesulitan tersendiri lebih dari kesulitan pemahaman konsep yakni saat menghitung menggunakan prinsip matematika dasar, masih belum tepat saat melakukan perhitungan, selain itu taruna menggunakan rumus yang kurang tepat hingga jawaban akhir yang dihasilkan tidak sesuai. Sehingga analisis perbedaan hasil belajar baik secara kuantitatif maupun kualitatif menunjukkan adanya perbedaan yang signifikan.

\section{UCAPAN TERIMA KASIH}

Penulis menyampaikan ucapan terima kasih pada Akademi Maritim Nusantara Cilacap yang telah mendukung dalam bentuk sarana serta prasarana pada kajian ini, ucapan terima kasih juga diberikan kepada taruna Teknika dan Nautika yang telah menjadi subjek pada kajian ini.

\section{DAFTAR PUSTAKA}

Amaliyah, M., Suardana, I. N., \& Selamet, K. (2021). Analisis Kesulitan Belajar dan Faktor-Faktor Penyebab 
4792 Perbedaan Hasil Belajar ditinjau dari Pemahaman Konsep dan Perhitungan Matematis pada Pembelajaran Fisika Terapan - Lusiani

DOI: https://doi.org/10.31004/edukatif.v3i6.1493

Kesulitan Belajar IPA Siswa SMP Negeri 4 Singaraja. Jurnal Pendidikan Dan Pembelajaran Sains, 4(1), 90-101.

Azmi, F., Halimah, S., \& Pohan, N. (2017). Pelaksanaan Pembimbingan Belajar Aspek Kognitif, Afektif dan Psikomotorik Siswa di Madrasah Ibtidaiyah Swasta Amal Shaleh Medan. Jurnal At-Tazakki, 1(1), 1528.

Betwan. (2019). Pentingnya Evaluasi Afektif pada Pembelajaran PAI di Sekolah. Al-Fikri: Jurnal Studi Dan Penelitian Pendidikan Islam, 2(1), 45-60. http://jurnal.unissula.ac.id/index.php/fikri/article/view/4015

Dewi, H. R., \& Yusro, A. C. (2016). Analisis Kesulitan Belajar Ipa Materi Gerak Pada Siswa Kelas VII MTs Sunan Ampel. Seminar Nasional Pendidikan Fisika II 2016, 19-23.

Djazari, M., \& Sagoro, E. M. (2011). Evaluasi Prestasi Belajar Mahasiswa Program Kelanjutan Studi Jurusan Pendidikan Akuntansi Ditinjau Dari Ipk D3 Dan Asal Perguruan Tinggi. Jurnal Pendidikan Akuntansi Indonesia, 9(2), 103-112. https://doi.org/10.21831/jpai.v9i2.970

Hakim, A., \& Rambe, D. (2012). Perbedaan Hasil Belajar Fisika dengan menggunakan Model Pembelajaran Kooperatif Tipe NHT dan Model Konvensional pada Materi Pokok Besaran dan Satuan. Jurnal Pendidikan Fisika, 1(2), 7-12.

Hanifah, N. (2016). Perbedaan Hasil Belajar Materi Elastisitas melalui Model Pembelajaran Kooperatif Tipe Jigsaw dan Student Archievment Division 9STAD) Siswa Kelas X SMA Negri 5 Banda Aceh. Jurnal Ilmiah Mahasiswa (JIM) Pendidikan Fisika, 1(3), 67-73.

Haqiqi, A. K., \& Sa'adah, L. (2018). Deskripsi Kesulitan Belajar Materi Fisika pada Siswa Sekolah Menengah Pertama (SMP) Di Kota Semarang. Thabiea: Journal of Natural Science Teaching, 1(1), 39-43. https://doi.org/10.21043/thabiea.v1i1.4044

Hidayatulloh, A. (2020). Analisis Kesulitan Belajar Fisika Materi Elastisitas Dan Hukum Hooke Dalam Penyelesaian Soal - Soal Fisika. Kappa Journal, 4(1), 69-75. https://doi.org/10.29408/kpj.v4i1.1636

Kallesta, K. S., Yahya, F., \& Erfan, M. (2018). Analisis Faktor Penyebab Kesulitan Belajar IPA Fisika pada Materi Bunyi Kelas VIII SMP Negeri 1 Labuhan Badas Tahun Ajaran 2016 / 2017 Avaliable online at : http://journal.lppmunsa.ac.id/index.php/quark Avaliable online at : http://journal.lppmunsa.ac.id/. Jurnal Inovasi Pembelajaran Fisika Dan Teknologi, 1(1), 51-58.

Mahananingtyas, E. (2017). Hasil Belajar Kognitif, Afektif dan Psikomotor melalui penggunaan jurnal belajar bagi mahasiswa PGSD. Prosiding Seminar Nasional HDPGSDI Wilayah IV, 192-200.

Maisaroh, \& Rostrieningsih. (2010). Peningkatan Hasil Belajar Siswa dengan menggunakan Metode Pembelaaran Active Learning Tipe Quiz Team pada Mata Pelajaran Keterampilan Dasar Komunikasi di SMK Negeri 1 Bogor. Jurnal Ekonomi \& Pendidikan, 8(2), 157-172. https://doi.org/10.1016/B978-0323-60984-5.00062-7

Nurbudiyani, I. (2013). Pelaksanaan Pengukuran Ranah Kognitif, Afektif, dan Psikomotor pada Mata Pelajaran IPS Kelas III SD Muhammadiyah Palangkaraya. Pedagogik Jurnal Pendidikan, 8(2), 14-20.

Nurfajri, E., \& Rochmawati. (2021). Pengaruh Kecerdasan Emosional dan Kecerdasan Logis Matematis terhadap Tingkat Pemahaman Akuntansi Mahasiswa dengan Minat Belajar sebagai Variabel Intervening. Edukatif: Jurnal Ilmu Pendidikan, 3(4), 1612-1622.

Nurjanah, S., \& Sunarto, S. (2018). Analisis Kesulitan Dalam Menyelesaikan Soal-Soal Fisika Materi Usaha Dan Energi Siswa Kelas X SMK Taman Karya Jetis Yogyakarta. COMPTON: Jurnal Ilmiah Pendidikan Fisika, 5(2), 21-26.

http://www.jurnal.ustjogja.ac.id/index.php/COMPTON/article/view/4161

Nurtanto, M., \& Sofyan, H. (2015). Implementasi Problem-Based Learning Untuk Meningkatkan Hasil Belajar Kognitif, Psikomotor, Dan Afektif Siswa Di Smk. Jurnal Pendidikan Vokasi, 5(3), 352. https://doi.org/10.21831/jpv.v5i3.6489 
4793 Perbedaan Hasil Belajar ditinjau dari Pemahaman Konsep dan Perhitungan Matematis pada Pembelajaran Fisika Terapan - Lusiani

DOI: https://doi.org/10.31004/edukatif.v3i6.1493

Putra, H. D., Setiawan, H., Nurdianti, D., Retta, I., \& Desi, A. (2018). Kemampuan Pemahaman Matematis Siswa Smp Di Bandung Barat. Jurnal Penelitian Dan Pembelajaran Matematika, 11(1). https://doi.org/10.30870/jppm.v11i1.2981

Rahmawati, L. F., \& Ali, M. (n.d.). Perbedaan Hasil Belajar Fisika antara Model Pembelajaran Sains Teknologi Masyarakat dan Model pembelajaran Direct Instruction pada Siswa Kelas X SMA Negeri 1 Palu. Jurnal Pendidikan Fisika Tadulako (JPFT), 1(1), 48-54.

Suardin, S., \& Andriani, W. O. L. (2021). Studi Komparatif Model Problem Solving Dengan Model Teams Games Tournament (Tgt) Terhadap Hasil Belajar Matematika Siswa Sekolah Dasar. Edukatif: Jurnal Ilmu Pendidikan, 3(1), 227-234. https://doi.org/10.31004/edukatif.v3i1.289

Sulastri, Imran, \& Firmansyah, A. (2015). Meningkatkan Hasil Belajar Siswa Melalui Strategi Pembelajaran Berbasis Masalah Pada Mata Pelajaran IPS Di Kelas V SDN 2 Limbo mMakmur Kecamatan Bumi Raya. Jurnal Kreatif Tadulako Online, 3(1), 90-103. 